\title{
Resale Pricing as Part of Franchisor Know-How
}

\author{
Dr. Rozenn Perrigot \\ Graduate School of Management (IGR-IAE Rennes) \\ CREM UMR CNRS 6211 \\ University of Rennes 1 \\ 11 rue Jean Macé - CS 70803 \\ 35708 RENNES Cedex 7 - France \\ rozenn.perrigot@univ-rennes1.fr \\ Dr. Begoña López-Fernández \\ Facultad de Economía y Empresa \\ University of Oviedo \\ Avda del Cristo, s/n \\ 33071 Oviedo - Spain \\ blopez@uniovi.es \\ Dr. Guy Basset \\ Graduate School of Management (IGR-IAE Rennes) \\ CREM UMR CNRS 6211 \\ University of Rennes 1 \\ 11 rue Jean Macé - CS 70803 \\ 35708 RENNES Cedex 7 - France \\ guy.basset@univ-rennes1.fr \\ Dr. Olivier Herrbach \\ IAE Bordeaux \\ University of Bordeaux \\ 35 avenue Abadie \\ 33100 Bordeaux - France \\ olivier.herrbach@u-bordeaux.fr
}

Acknowledgements: The authors acknowledge the International Society of Franchising for the Best Paper Award they received at the 2019 conference as well as the Spanish Ministry of Economy and Competitiveness (ECO2017-85704-R) for its valuable support.

Version accepted for publication in

Journal of Business \& Industrial Marketing

On February 2020, $11^{\text {th }}$

https://doi.org/10.1108/JBIM-05-2018-0145 


\title{
Resale Pricing as Part of Franchisor Know-How
}

\begin{abstract}
Purpose: As franchisees are independent entrepreneurs, one important part of the business format that franchisors are not allowed to impose on their franchisees is resale prices. They are only allowed to indicate a recommended or a maximum price. This study looks further into the capabilities underlying the calculation of resale prices and suggests that price-setting is part of both: the "business know-how" transferred to franchisees and the "organizational know-how", that is, capabilities developed and kept at the franchisor level.
\end{abstract}

Design/methodology/approach: We adopted a qualitative methodology with a total of 65 interviews, 19 with franchisors and 46 with franchisees, all operating in the French market.

Findings: Our findings show that resale pricing is a process that involves know-how. The complexity of pricing leads to develop specialized and broad capabilities. The first type of know-how, i.e., business know-how transferred to franchisees, deals with operational implementation of recommended resale prices in the stores. The second type, i.e., organizational know-how, not transferred as a safeguard against opportunism, connects across other functions of the franchise chain such as $R \& D$, communication, etc.

Originality/value: We confirm the existence and relevance of another kind of know-how apart from the business know-how that is transferred to the franchisees. Organizational knowhow at the chain level, though often neglected, is a necessary determinant of sustaining a competitive advantage. This know-how is not transferred to the franchisees but contributes to the success and sustainability of the franchisor/franchisee relationship. Franchisors should thus work on improving their capabilities to better support their franchisees. Moreover, we highlighted the complexity and extreme importance of setting the right resale price.

Keywords: Franchising, Know-How, Resale Pricing, Capabilities. 


\section{INTRODUCTION}

Franchising has been growing in many countries and in many industries (Hoy et al., 2017). Even though US fast-food franchise chains are the archetypal franchise chains, franchising is neither limited to the US market nor to the fast food industry. Rather, it is steadily developing worldwide and in many industries, such as clothing, supermarkets or homecare services.

Franchising is "based on the business (i.e., franchisor)-to-business (i.e., franchisee) relationship, where there is a mutual benefit that requires a long-term cooperation" (Doherty and Alexander, 2004, as cited in Kim and Stepchenkova, 2018). It is "a contractual arrangement between two independent firms, whereby the franchisee pays the franchisor for the right to sell the franchisor's product [and/or services] and/or the right to use his trademark at a given place and for a certain period of time [...]. [T]he relationship between franchisor and franchisees 'includes not only the product, service, and trademark, but the entire business format itself - a marketing strategy and plan, operating manuals and standards, quality control, and continuing two-way communication [...]” (Lafontaine, 1992, p. 264).

In other words, franchisors transfer to their franchisees a set of know-how comprising practical knowledge and capabilities (Watson et al., 2005), resulting from their own experience and previous tests often conducted in their company-owned stores. Additionally, franchisors allow their franchisees to use a brand perceived to be valuable and provide them with continuous assistance (Michael, 1999). Franchisors seek to offer a uniform image to customers to guarantee a consistent service associated with the brand (Kaufmann and Eroglu, 1999; Kosová and Lafontaine, 2012), whatever the location of each franchised store and regardless of who owns the store, a franchisee or the company itself.

This uniform image includes product assortment, merchandising, store decor, services, and also resale pricing. Resale prices are the prices paid by the final customers to purchase the 
products and/or services of their choice in the stores. In a company-owned chain, store managers are employees and not independent entrepreneurs, so the chain headquarters are free to set up and impose the resale prices that will be displayed in all the stores. However, in a franchised chain, some - if not all - stores are franchised and run by franchisees who are independent entrepreneurs. As such, franchisees can set up their own resale prices on the products and/or services they sell in their local stores. Therefore, chain uniformity is not ensured when it comes to pricing, although this marketing-mix variable is part of the knowhow (Dutta et al., 2003; Liozu and Hinterhuber, 2013). Indeed, according to the Commission Regulation (EU) No 330/2010 ${ }^{1}$, franchisors are not allowed to impose resale prices on their franchisees. Franchisors are only allowed to indicate a recommended price or a maximum price (Basset and Perrigot, 2015). In the UK, the "Competition Act 1998 generally allows a franchisor to recommend or set a maximum price for goods or services sold by its franchisees, provided this does not in practice constitute a fixed or minimum price"². Outside the European market, similar rules apply to the Australian market where franchisors can provide recommended resale prices to their franchisees and where they generally set maximum resale prices. ${ }^{3}$ As far as the US are concerned, antitrust regulation is more severe for minimum than for maximum resale prices (Blair and Lafontaine, 2005).

Despite their non-compulsory nature, the use of recommended prices raises several questions because they may affect the appropriation of value and the uniform image of the franchise chain. Are recommended prices part of the know-how transferred by the franchisor to the franchisees? How do franchisors determine recommended prices? Does price setting require specific resources and capabilities, and thus imply organizational know-how at the

\footnotetext{
${ }^{1}$ Commission Regulation (EU) No 330/2010 of 20 April 2010 on the application of Article 101(3) of the Treaty on the Functioning of the European Union to categories of vertical agreements and concerted practices and its Guidelines on Vertical Restraints.

${ }^{2}$ https://www.thebfa.org/news/bfa-news/resale-price-maintenance-and-franchising-latest-updates/ https://iclg.com/practice-areas/franchise-laws-and-regulations/england-and-wales

${ }^{3}$ https://www.accc.gov.au/update/franchising-code-frequently-asked-questions\#can-a-franchisor-set-prices-
} 
franchisor level to achieve a competitive advantage? This study intends to respond to these questions.

Our research objective is to determine if resale pricing can be considered part of the franchisor's know-how and, more specifically, part of the "business know-how" that is transferred from the franchisor to the franchisees and/or part of the "organizational knowhow," referring to franchisor capabilities that are not transferred to the franchisees. It is important at this stage, even though we will go into the detail in the next section, to distinguish "business know-how" and "organizational know-how". On the one hand, "business know-how", also found as know-how or operational know-how, refers to the knowhow almost always mentioned in definitions of franchising, i.e., the one that enables franchisees to run their business on a daily basis and that it is transferred through initial and ongoing training, visits of the on-field consultants, among others, from the franchisor to the franchisees. On the other hand, "organizational know-how" refers to competences or capabilities of the franchisor and his/her staff at the chain headquarters that will not be necessarily and directly transferred to the franchisees but that will have positive externalities for the franchisees (Perrigot et al., 2011).

The empirical study dealt with the French franchise sector, which is one of the leading markets for franchising in Europe. Adopting a qualitative approach, we used a dual perspective involving a total of 65 interviews, 19 with franchisors and 46 with franchisees.

The findings of such an empirical research are useful because, on the one hand, the question of resale pricing in franchising is a hot topic, due to its relationships with chain consistency and brand image (Winter et al., 2012), chain attractiveness vis-à-vis the customers, chain differentiation from the competitors, and franchisee independence (Perrigot et al., 2016). However, the dispersion of this marketing decision has only been explored to a limited extent in business-to-business contexts (Blachetta and Kleinaltenkamp, 2019). On the 
other hand, franchisors are usually assessed based on their know-how, in terms of how this later is protected to be kept secret, of how well identified it is in the operational manual, of how substantial it is for the franchisees (Knott, 2003; Winter, et al., 2012). Moreover, the organizational know-how, as part of the franchise management capabilities, has not caught the attention of researchers so far, despite its relevance at the operational level for the management and the development of the chain. An exception is a very recent research of Gillis et al. (2020) on such capabilities ${ }^{4}$ in link with the chain performance. Matching the two topics, resale pricing and know-how, is thus of high interest for academics as well as franchisors and franchisees. The originality of our study relies on the focus on organizational know-how and the matching of know-how and resale pricing.

This research offers a number of contributions. Firstly, we build on the literature dealing with know-how in franchising (Paswan and Wittmann, 2009; Perrigot et al., 2017; Windsperger and Gorovaia, 2011) that Iddy and Alon (2019) considered underdeveloped in their review of knowledge management in franchising over the past 29 years. Particularly, Iddy and Alon (2019) highlighted topics that deserve further attention; they deal with absorptive capacity and replication vs. adaptation strategies that are related to transfer of pricing capabilities. Secondly, we contribute to the stream of literature dealing with resale prices in franchising (Basset and Perrigot, 2015; Perrigot and Basset, 2018; Perrigot et al., 2016; Stassen, 2017) by showing that resale pricing is part of franchisors' business and organizational know-how, and that both types of know-how are interrelated addressing the recent call by Gillis et al. (2020) for more research on the franchisor capabilities that allow franchisors and their franchisees to work together in an efficient way. This is the first known

\footnotetext{
${ }^{4}$ Gillis et al. (2020) define franchise management capabilities as "the main cognitive, behavioral, and organizational routines that enable a franchisor to achieve both standardization and adaptation in working with franchisees". These capabilities have three dimensions, i.e., knowledge-sharing routines, standard operating routines and trust routines. The first and the second ones are closely associated with know-how.
} 
study exploring the relationships between know-how and resale pricing and distinguishing both types of know-how (business and organizational). Thirdly, we offer insights by combining both franchisor and franchisee perspectives. Indeed, most research deals with either a franchisor approach or a franchisee approach; a few exceptions are those of El Akremi et al. (2011) and Mignonac et al. (2015). In the specific case of resale pricing in franchising, for instance, Perrigot et al. (2016) adopted a franchisee approach whereas Perrigot and Basset (2018) used a franchisor approach.

The paper is organized as follows. In section 2, we review the literature. Section 3 describes the methodology. In Section 4, we present the main findings of our empirical study and formulate research propositions. Section 5 consists of a discussion of these findings.

\section{LITERATURE REVIEW}

\subsection{Resale prices in franchising}

Uniformity and consistency are major issues for franchise chains (Ater and Rigbi, 2015; Bradach, 1997; Kaufmann and Eroglu, 1999; Kosová and Lafontaine, 2012). These features are valuable as they ensure the predictability of the product quality, the level of services, the price range, the atmosphere, etc. for customers. Customers usually expect resale prices to be quite uniform across the stores. Uniformity and consistency are also important for franchisors and franchisees in order to reinforce the brand image, for releasing national advertising campaigns and to satisfy customers. In contrast, decentralized price decisions made by franchisees who are independent small business owners may harm the chain brand image for the sake of individual profitability.

Whereas the headquarters of a company-owned chain can set resale prices for the stores, in franchising, reaching a consensus in pricing policies is challenging because 
franchisors and franchisees have different views on appropriate prices. Franchisors have chain-wide considerations (e.g., chain uniformity, intra-chain competition) when determining the right resale prices, while franchisees, at the opposite spectrum, have local considerations when setting resale prices (Lafontaine, 1999). Franchisees, when deciding on the resale prices try to meet their local customer expectations and take into account their local competitors (Pardo-del-Val et al., 2014).

On the one hand, franchisors' revenues stemming from franchisees are directly related to store sales and not store profit, as is the case for franchisees. So, franchisors will often prefer to set lower prices that maximize sales (if demand is elastic) even if profits are eroded. On the other hand, franchisees may prefer to overprice the products and/or services they sell compared to the level that maximizes chain profits (Zanarone, 2009). In fact, past research has unveiled higher prices in franchised stores stemming from double marginalization (Ater and Rigbi, 2015; Lafontaine, 1999; Lafontaine and Morton, 2010; Zhang et al., 2015).

In order to balance chain consistency and franchisee autonomy, common franchise chain practices deal with recommendations of resale prices by franchisors to their franchisees. Indeed, EU legislation, just like most national laws in effect across the Member States (Arhel, 2001) or like US anti-trust laws, accept the principle that franchisors may recommend a resale price to their franchisees or impose a maximum resale price limit, but prohibit franchisors from imposing a minimum resale price or a fixed resale price on their franchisees.

Recommended prices can take several forms: price grids, price scales, price ranges, price lists transferred from franchisors to their franchisees, or methods for setting prices, usually based on accounting aspects and raw material costs, competition benchmark and prices that the consumers are willing to pay (Hinterhuber and Bertini, 2011), specially these latter are relevant because value-based pricing improves performance (Lizou and Hinterhuber, 
2013). In many cases, franchisors will control that recommended prices are applied in the franchisee stores, using outcome-, behavior- and/or social-based control systems (Vázquez, 2008). Even if franchisees may consider autonomy in resale pricing desirable, when it comes to making a decision, Bradach (1998) found that, very often, franchisees mimic the franchisor prices, reproducing them or using prices in company-owned stores as a benchmark for calculating their own margins.

\subsection{Business know-how in franchise chains}

Franchisee candidates usually join franchise chains in order to increase their competitive advantage in the local market (Michael, 1999). Indeed, collaborations among such independent companies, in our case the franchisor and the franchisees, may reinforce strengths and correct weaknesses (Simonin, 1997).

According to the Resource-Based View (RBV) (Barney, 2002; Newbert, 2008; Wernerfelt, 1984), a competitive advantage stems from internal resources and capabilities of the company rather than the external forces of the market (Suh et al., 2019). These internal resources usually refer to tangible and intangible (knowledge-based) assets that comprise a set of know-how in the particular context of franchising. As Paswan and Wittmann (2009) explained, "franchisors sell the know-how and benefits of the business system to prospective franchisees". Windsperger and Gorovaia (2011) also asserted that the success of a chain depends on the correct transfer of know-how from franchisor to franchisees. Indeed, knowledge transfer capabilities are a source of competitive advantage (Winter et al., 2012).

Know-how is defined as "a body of non-patented practical information, resulting from experience and testing by the Franchisor, which is secret, substantial and identified" 
(European Code of Ethics for Franchising) ${ }^{5}$. Specifically, know-how is composed of information on "every aspect of the franchise business, and in particular technical, commercial, promotional, publicity, administrative and financial matters, staff training and general administration." ${ }^{96}$ Beyond these definitions based on regulatory provisions, information is an input to knowledge, but knowledge adds an interpretation by individuals at a given context and it is rooted in the beliefs and commitments of individuals (Nonaka et al., 2000). Therefore, the transfer of know-how involves information as well as appropriate understanding of the recipients, i.e., the franchisees. If we interpret Nonaka et al.'s (2000) model in the specific case of franchising, franchisee knowledge is created through interactions between tacit and explicit knowledge as it happens in the process of transferring franchising know-how, where explicit fonts overlap socialization and training of the franchisees.

Unlike other partnerships, in franchising, franchisors sign standardized contracts regarding know-how, with different partners within the same industry. Simonin (1997) explained that collaborative know-how is a multifaceted capability generated in alliances that involves four phases of a collaboration cycle: $1 /$ identifying potential partners, 2 / negotiating the agreement, 3/ monitoring and managing the collaboration, and 4/ terminating the alliance. The third of these phases, monitoring and managing the ongoing collaboration, encompasses transferring resources and training, among others. This phase corresponds to the transfer of know-how in franchising, also called "business know-how", that contains knowledge-based resources and capabilities. These capabilities are what the company can do with resources (Grant, 2016, Grant and Jordan, 2015) because, to be useful, know-how should provide

\footnotetext{
${ }^{5}$ It almost reproduces the wording of article 1-1 (g) of the Commission Regulation (EU) No 330/2010.

${ }^{6}$ 87/14/EEC: Commission Decision of 17 December 1986 relating to a proceeding under Article 85 of the EEC Treaty (IV/31.428 to 31.432 - Yves Rocher), Official Journal L 008 , 10/01/1987 P. 0049 - 0059, paragraph 22 (http://eurlex.europa.eu/LexUriServ/LexUriServ.do?uri=CELEX:31987D0014:EN:HTML).
} 
franchisees with skills to run their outlet including proposals of the products and/or services at the customers at the right resale prices.

Additionally, and as mentioned above, know-how in franchising must be secret, substantial and identified. Similarly, the RBV states that some resources and capabilities must be "secret" to succeed, what implies difficulty of imitation that may derive from uniqueness, path dependency and/or causal ambiguity (Reed and DeFilippi, 1990). "Secret" means "that the know-how is not generally known or easily accessible; it is not limited in the narrow sense that each individual component of the know-how should be totally unknown or unobtainable outside the Franchisor's business." (European Code of Ethics for Franchising)

Franchisors can transfer some know-how that, sometimes, can be, in a sense, easy to imitate, and therefore not sustainable over time even if it was original at the first time. For instance, franchisors transfer store designs, product assortment, certain business practices, recipes, recommended prices, etc. However, the competitive advantage may lie in the combination of those elements (Knott, 2003), their updates and the connection with other elements, such as the brand name, that are difficult to imitate due to causal ambiguity and path dependency (Reed and DeFilippi, 1990). Know-how may contain a combination of practices difficult to replicate, to substitute or to disentangle which specific practices lead to success (Winter et al., 2012). Additionally, those practices may be connected with other elements like the brand making it costly to accelerate practice upgrading. Indeed, sometimes, they are developed by the franchisor investing in different marketing activities and learning from experience for a long period (Bordonaba-Juste et al., 2011; Michael, 1999). Instead, practices and reputation must be built over time with effort and iterations of learning (Dierickx and Cool, 1989; Michael, 1999; Suh et al. 2019). 
Moreover, the requirement of being "substantial" may lead to competitive superiority and the requirement of being "identified" may simplify the appropriability of the rents derived from know-how because it makes the ownership of the know-how clear.

The transfer of a set of know-how from franchisors to franchisees is at the heart of franchising (Knott, 2003) and is part of the franchise management capabilities (Gillis et al., 2020). The franchisor must convey know-how to the franchisees joining the chain for the franchisees to be able to apply it and thus reiterate the success of the franchisor. This knowhow also allows the franchisees to provide uniform products and services at similar prices to final customers, and so offer a uniform brand image (Sorenson and Sørensen, 2003).

Transferred know-how may be in a written format (through an operations manual often called the "bible of the franchisor," files, software, CD-ROM, etc.) for explicit knowledge. Oral formats (training sessions at franchisor headquarters, practical training sessions in company-owned or franchised stores) and visual formats (videos, websites, etc.) can also be used for improving understanding and develop capabilities of the franchisees (Basset and Perrigot, 2015). In transferring their know-how, franchisors use different tools: operations manual, emails and internet, initial training sessions, discovery sessions, ongoing training, regional meetings, committees, informal personal contacts, on-field consultants (Perrigot et al., 2017).

Know-how may create value for customers, however, to appropriate the rents (profits) associated with that value, firms must set the right prices (Dutta et al., 2003) and communicate that value to customers (Liozu and Hinterhuber, 2013). Drawing on the works of Grant and Jordan (2015) and Johansson et al. (2015), we define value as the customer's willingness to pay, that should be larger than price and larger than cost, otherwise customers will not buy and franchisors and franchisees will not obtain rents. Franchisors should consider 
these aspects of value when setting resale prices and transferring them to their franchisees, because prices convey not only quantitative information, but also capabilities that let franchisees understand how to adapt prices to their specific stores. Pricing process has been acknowledged as a valuable capability (Dutta et al., 2003; Grant and Jordan, 2015).

\subsection{Organizational know-how in franchise chains}

Franchisors do not only develop and master business know-how to be transferred to their franchisees, but they also develop and master know-how related to chain management, called “organizational know-how” (Perrigot et al., 2011). For instance, franchisors organize training sessions in order to transfer to their franchisees a set of business know-how, but the very design of the training sessions (e.g., duration, mix of in-class training and practical training, use of role play) relies on capabilities, i.e., organizational know-how. Another example deals with advertising campaigns. Franchisors can provide their franchisees with templates of flyers for which the franchisees add the address of their stores and the resale price. The franchisors may not necessarily explain in detail why they have chosen a specific picture, specific font, etc., and they will not necessarily train franchisees to design their own flyers.

This part of the franchisor's organizational know-how is a cross-functional or broad functional capability that embodies narrower capabilities (Grant and Jordan, 2015) related to specific aspects of the business. In fact, some capabilities that are broad in scope, crossfunctional and related to the management and governance of the chain may remain at headquarters. Franchisors may only transfer certain instructions or business know-how (specialized capabilities) that stem from that broad knowledge to enable franchisees to replicate the template. We then suggest that business know-how is a capability that is organized hierarchically from specialized to broad capabilities that only franchisors master. Franchisor organizational know-how depends on his/her capacities to coordinate the creation, 
improvement and transfer of his/her business know-how on a long-term basis in order to sustain the competitive edge, as this is the case in strategic alliances (Simonin, 1997). Franchisor organizational know-how also depends on his/her capacity to manage relationships with franchisees in order to prevent potential conflicts or to ensure the replication of the franchise concept in all locations because in case of failure of collaboration, parties may use the acquired capabilities against the former partner who provided them (Simonin, 1997; Lee et al., 2015). Both types of know-how have to be considered in a broader context with contractual relationships and human relationships, as reflected in Figure 1. So, franchisors can transfer only a part of the know-how to protect themselves from opportunistic imitation. As observed by Suh et al. (2019), partnerships are affected by the type of the knowledge that is shared. Franchisors who develop trusting relationships with their franchisees effectively transfer and replicate know-how.

Resale pricing entails a broad capability that relies on franchisor knowledge of the impact of different aspects of the overall service, of other stores in the chain (intracompetition) and of other functions of the chain, particularly marketing communication and finance, on sales as observed in other business-to-business relationships (Blachetta and Kleinaltenkamp, 2019). It enables franchisor and franchisees to appropriate a profitable portion of the value created in the relationship (Dutta et al., 2003; Johansson et al., 2015) and value pricing "cut across a multitude of functions of the firm" (Johansson et al., 2015, p. 179) as a broad capability. Although it is the most tactical element of the marketing-mix, because it is easy to modify and to imitate, franchisees may find it difficult to develop the skills to set an appropriate price and to anticipate the consequences of a given price on their own businesses (e.g., increase of sales) and the whole chain (e.g., intra-chain competition or cannibalization of other items of the assortment). Firms, and particularly franchisors, must develop capabilities in terms of pricing processes to appropriate the value they may generate, and 
those capabilities are difficult to imitate because they must be tailored to the firm and to customer requirements (Dutta et al., 2003).

\section{METHODOLOGY}

In order to assess if resale pricing can be considered part of the franchisor's know-how, we conducted an empirical study using a qualitative approach. This empirical study dealt with the French franchise market. France is one of the leading markets in franchising in Europe with 2,004 franchisors, 75,193 franchised stores, 62.01 billion $€$ of total revenues (French Franchise Federation, 2019). Franchising has been continuously growing in France in both the retail and service industries. Its international dimension should be highlighted, too, as France is not only attractive to foreign franchisors (e.g., Burger King, Five Guys, Papa John's, Pita Pit in the fast-food industry), but also exports many franchise concepts in foreign countries (e.g., Brioche Dorée, Carrefour, Ibis).

We adopted a qualitative approach, conducting in-depth semi-structured interviews with franchisors or high-level managers of franchise chains, as well as franchisees. Qualitative approaches have been used in previous research on franchising on such topics as the plural form (e.g., Perrigot and Herrbach, 2012), know-how transfer (Perrigot et al., 2017) and multi-unit franchising (Weaven and Frazer, 2007). Most of these qualitative studies have dealt with the franchisee perspective (e.g., Croonen, 2010; Frazer and Winzar, 2005; Weaven and Frazer, 2006). A few other studies have dealt with the franchisor perspective (e.g., Doherty, 2009; Kirby and Watson, 1999; Perrigot and Basset, 2018). In this study, we used a dual perspective (Frazer et al., 2012), including 65 interviews with both franchisors and franchisees. This perspective was relevant to better understand if, why, and how resale pricing is part of franchisor know-how according to both parties of the franchise relationship. 
The franchisors and franchisees we interviewed were chosen purposively to provide relevant and diversified information about the way they consider the links between resale pricing and franchisor know-how. The purposive sampling, i.e., "the deliberate choice of a participant due to [his/her] qualities" is "typically used in qualitative research to identify and select the information-rich cases for the most proper utilization of available resources" (Etikan et al., 2016, p. 2).

As far as franchisor interviews were concerned, we met 19 executives and high-level managers of franchise chains (e.g., directors of marketing, franchise chain CEOs, franchise directors, on-field consultants), all operating different chains in the French market in various areas of the retail industry (e.g., fashion, gourmet food, kitchen supply, optometrist) and various areas of the service industry (e.g., fast food, hotels, business services, hairdressing), and with various chain sizes, chain ages, and mixes of franchised and company-owned stores within the chains. They also had different backgrounds and levels of seniority within their chains. Because executives and high-level managers of franchise chains work at the chain level, they provided us with a global overview of practices associated with resale pricing and know-how found in their chain (many times, they had several cases encountered with different franchisees to explain to us) as well as in the franchise sector. We considered that we had reached the theoretical saturation with these 19 interviews (Glaser and Strauss, 1967; Huberman and Miles, 2002).

As far as franchisee interviews were concerned, we conducted 46 interviews with franchisees, all located in France. The profiles of the interviewees varied in terms of industry (retailing: fashion, gourmet food... and services: fast food, beauty store with face and body care...), or brand even though, contrary to the franchisor approach for which we had one interviewee per chain, here for the franchisees, we interviewed several franchisees from the 
same chain ${ }^{7}$, or location of their stores, as well as previous experiences and levels of seniority in their franchise chains. Because franchisees usually have a more limited perspective on the chain business and practices, being mostly focused on local aspects of their stores, we had to interview more franchisees than franchisors to get a global overview of resale pricing and know-how in franchising from such a franchisee perspective. Moreover, the franchisee interviews were usually shorter than the franchisor ones, so a little less rich, that is also a reason why we wanted to get a higher number of franchisees interviewed. We considered that we had achieved the theoretical saturation with the 46 interviews (Glaser and Strauss, 1967; Huberman and Miles, 2002).

In addition to the usual introduction and conclusion, the interview guides we used with franchisors and franchisees covered the following topics:

1. franchisor and franchisee roles and practices in terms of resale pricing (examples of questions for the franchisors: Why is resale pricing important? Could you explain to me how resale prices are set up in the chain? How do you build recommended prices? How do you transfer these recommended prices to your franchisees? etc.; examples of questions for the franchisees: Why is resale pricing important? Could you explain to me how resale prices are set up in the chain? How does your franchisor build recommended prices? How does your franchisor transfer you and your fellow franchisees these recommended prices? etc.),

2. the relationship between resale pricing and franchisor/franchisee relationship (examples of questions for the franchisors: Do you involve your franchisees in resale price setting? If yes, how? Do you explain them how you build the recommended prices? etc.; examples of questions for the franchisees: Are you involved in resale

\footnotetext{
${ }^{7}$ A few of the franchisees we interviewed belonged to chains for which we had interviews with the franchisors.
} 
price setting? If yes, how? Does your franchisor explain you how the recommended prices are built? etc.),

3. performance and conflicts (examples of questions for the franchisors: How can uniform resale prices across the stores lead to a better image, a higher customer satisfaction and a higher performance? Have you already faced some tensions and/or conflicts about recommenced prices with franchisees? If yes, which kinds? etc.; examples of questions for the franchisees: Do you think applying recommended prices in all the stores is important for the brand image, the customer satisfaction and the performance? Have you or some of your fellow franchisees already had tensions/conflicts about recommended prices with your franchisor? What were the reasons of such tensions/conflicts? etc.).

The 65 interviews were audio-recorded and fully transcribed. The transcribed interviews in French were analyzed, and the relevant verbatim quotes were then translated into English. The average length of the interviews was 54 minutes for those conducted with franchisors (from 25 minutes to 1 hour, 40 minutes), and 49 minutes for franchisee interviews (from 18 minutes to 2 hours, 3 minutes).

The interviews were analyzed using a two-step process, as suggested by Saldaña (2015). In their book on qualitative data analysis, Miles et al. (2014, p. 73) explained that according to Saldaña (2013), coding can be divided into two major stages: first cycle coding (that gathers various approaches) and second cycle coding. In the first cycle of coding, descriptive coding (i.e., words or short phrases) was chosen to assign symbolic meaning to the information provided in the interviews. The objective was to summarize segments of data (Miles et al., 2014, p. 74). In the second cycle of coding, also named pattern coding, the data segments were grouped into themes in order to get "more meaningful and parsimonious units of analysis" (Miles et al., 2014, p. 86). In this paper, we exclusively focused on findings 
dealing with resale prices and know-how. In terms of data coding, in a first step, we observed for instance, that several sentences in the various interviews, were referring to resale prices as detailed and explained in the operations manual, we then grouped these sentences or verbatims in a theme named "operations manual". And in a later step, "operations manual" appeared to be only one way among others to transfer recommended prices to franchisees, the other being the Intranet, the training sessions, and the on-field consultants. After going through the last set of interviews in our sample, we reached a point of saturation (Yin, 2003) where little new information was obtained and where similar patterns came back, which provides evidence for the validity of our findings. We paid particular attention to the reliability and validity of our research. Regarding reliability, the researchers involved in this research paper, with previous experience in qualitative methods, participated to the data analyses to ensure an agreement on categorization and structure of the data. Regarding validity, we discussed the findings of our study with some franchisors and franchisees during informal meetings. We thus get their feedbacks on these findings. We adopted a rigorous approach (Morse et al., 2002) from the elaboration of the interview guide to the presentation of the findings.

\section{FINDINGS}

\subsection{Recommended resale prices as part of the business know-how}

Recommended prices are transferred from the franchisor to the franchisees, among other elements of the franchisor business know-how. Usually franchisors will use different means of transfer for such recommended resale prices, as well as several tools. 


\subsubsection{Various ways to transfer recommended resale prices from the franchisor to}

\section{franchisees}

The interviews with franchisors and franchisees revealed that the recommended resale prices themselves, and information on these prices, are transferred from the franchisor to the franchisees through various means, including top-down (Intranet operations and manual) and more interactive ways (training sessions and on-field consultants).

Intranet: According to a few interviewees, mostly in the specialized food industry, the Intranet platform is used by franchisors to transfer their know-how related to recommended resale prices. One franchisor said: "We have an Intranet site on which we find all the recommended resale prices" (Director of chain development, \#8, specialized food industry). Another franchisor also mentioned: "We have an Intranet site. On this site, there are all the products with technical data sheets and [recommended] resale prices, too" (On-field consultant \#16, specialized food industry). A franchisee also explained: “[Very soon], we will have an Intranet portal. In fact, we will have a portal where we will have the purchase price, we will have the characteristics of the [product] and we will have its recommended resale price. [...] One can know the recommended resale price" (Franchisee \#37, specialized food industry).

Operations manual: A franchisor from the home care industry mentioned the operations manual as a way to transfer recommended resale prices to franchisees: "We talk about resale price grids [in the operations manual] knowing that our prices are evolving, so we always refer to the resale price grids. We explain very clearly in our sales methods what we can do to sell at higher resale prices, which means selling in the superior range. This is the main focus of the business. And we also explain the mechanics of profitability: how our margin is generated, how we maintain it, what to be aware of, etc." (Director of Chain Development and International Franchise Operations \#10, home care service industry). 
Training sessions: Several interviewees explained that recommended resale prices and the manner/technique by which to set them are transferred from the franchisor to the franchisees during the training sessions. For instance, a franchisor asserted: "We help [our franchisees] in our training to determine their resale price. We do not tell them 'That's the price!', [...], we tell them how they're going to determine their prices. [...] For me, it's really all about training. The price is always an essential part of a sale, so if the franchisee does not understand how the resale price is calculated, it's going to be complicated for him to sell [the product/service]" (Chain CEO \#4, business services industry). A franchisee explained: "When you join [Brand name], you have some training, especially training on resale pricing” (Franchisee \#5, specialized food industry).

On-field consultants: Some interviewees mentioned that on-field consultants play a role in the transfer of the know-how dealing with recommended resale prices. A franchisee in the fashion industry explained that on-field consultants monitor the proper implementation of the knowhow in terms of resale prices: "We have a regional director who visits us every two months, $[\ldots]$ to see if we follow the procedures, the recommended prices..." (Franchisee \#23, ready to wear industry). Another franchisee in the retail industry detailed the monitoring role of the onfield consultant in link with respect to the concept: "For example, the on-field consultant will visit me, she knows my prices, she will see [and say]: '[First name of the franchisee], your margin is too high. Don't be surprised if customers don't come'. [...] I have the right to do what I want, however, she [can] tell me 'Don't be surprised if it doesn't work, because you do not stick at all to the concept. The concept is not like that'. [...] I find it reasonable. We pay royalties and everything. It's not for nothing. And if we do not comply, if we do not bring 
know-how or prices to our customers, it is not worth it and it is better to be totally independent in this case" (Franchisee \#28, retail industry).

\subsubsection{Various tools used to transfer the recommended resale prices from the franchisor to}

\section{franchisees}

Many of the franchisors we interviewed use resale price grids, scales, ranges and lists as tools for their franchisees to apply the recommended resale prices. These tools are transferred to the franchisees during the training sessions, handed out by the on-field consultants, available on the Intranet platform or sent by email or by post.

A franchisor in the fast food industry explained: "Recommended resale prices, it's a grid, that's it. So we have three price categories, so A, B, C. [...] We have three different types of sandwiches, regular, mid-range and premium price [...] From there, we give them the recommended prices of each category between 3 and 3.50 euros between 4 and 4.50 and between 4.50 and 5 euros, and they do what they want. And at the menu level, the same. We give them directions at the menu level” (Development Agent \#7, fast food industry). Franchisees also noted the existence of such tools. One interviewee in the beauty industry stated: "They [i.e., the franchisors] give us a scale, obviously. Recommended prices for facial care as well as for body care. [...] We don't do what we want" (Franchisee \#46, beauty industry). In the same vein, a franchisor in the specialized food industry added that it is useful to provide a resale price range because franchisees do not always know how to set up their own prices: "We have to keep them [i.e., the resale prices] in a range [...] for the sake of the franchisee. [...] We have people from different backgrounds, [...] therefore, there is almost no one who has a notion of what the right resale price is. So, it's true that we are the ones who have to support them" (Regional Manager \#15, specialized food industry). 
Another interviewee explained that the price elements take into consideration the location of the stores: "We give them [i.e., the franchisees] everything, all our elements of resale price setting, and we tell them: 'Here, what we do in such and such geographical areas in France, this is what we recommend because we are sure these are the prices that are neither too expensive nor too cheap. [...] When we launch a new product or a new range, we give them all the elements as suggestion. [...]. They are told: 'here we are, outside the Paris area. We will position ourselves on this or that price for this or that product; in the Paris area, we will do that and within Paris itself, we will do like that" (On-field consultant \#5, fast food industry).

An interviewee also mentioned a price list sent to his franchisees: "We send them the price list to use and we send them this list roughly one month before implementation [of the new prices]" (Franchise Commercial director \#11, specialized food industry). Another interviewee referred to tools in general that are more and more difficult to read and to use: "There are many tools that exist ... [and] there are people who want to use the tools, but they do not know how to use them ... so the recommendation we will make, it is also to support them in understanding and [making] use of the new tools. [...] Our know-how, in fact, is both our ability to provide them with the tools and, at the same time, to bring them, to train them, and to get them to use these tools and to manage their resale prices in the best way" (Franchise director \#18, hotel and restaurant industry).

Because recommended resale prices are transferred from franchisors to their franchisees through various ways, among which Intranet, operations manual, training sessions, on-field consultants, and using various tools such as price grids, scales, ranges and lists, we can formulate the following proposition:

Proposition 1: Recommended resale prices are part of the franchisor business know-how. 


\subsection{Recommended resale prices as part of the organizational know-how}

Setting the right recommended prices is a difficult task for the franchisor, which requires capabilities at the franchise chain headquarters level, and thus organizational know-how. From this perspective, the experience of the franchisor via the company-owned stores, for instance, is important, as well as the involvement of the franchisees on specific committees.

\subsubsection{Difficulties franchisors face in setting the right recommended prices}

Most interviewees underlined the fact that setting the right recommended resale prices is a difficult task for the franchisor. It involves taking into consideration several criteria, such as the cost of the raw material, the competition, the demand, some macro elements like VAT increases or the margin. These criteria underline the fact that setting the right recommended prices requires capabilities at the franchise chain headquarters, and thus organizational knowhow.

As a franchisor from the fast food industry explained in detail: "Determining resale prices is very complicated, it's very technical and I think when you join a franchise chain, it's in order to get rid of all this fairly tedious work. [...] Setting up the right recommended prices takes a long time, it is tedious, [...]. We mobilize resources internally to make a competition benchmark. It takes time to recalculate the material cost of all the products in the range. It's the material cost. It's the labor cost. Finally, it's all commodity costs in fact, material costs, labor costs and packaging costs. So, all that takes a lot of time and then [to maintain] range consistency. [...] It's a job [setting] the price. It's really a job. So, we do it because we have a marketing department. [...]. Each of the regional directors must make a price benchmark [...]. He checks the prices. These are local price records. That's complicated. They had someone who was hired, a trainee, whose job was to study resale prices [in link with the prices of raw materials, the price of competitors]. [...] These are strong enough elements that allow 
determining the right prices. [...] There are more and more companies that hire 'pricers', people whose job is solely to determine prices" (On-field consultant \#5, fast food industry).

Another interviewee asserted that setting the right recommended price is not a random decision: "When you set a price for a product, you are in a market. You position yourself with respect to your competitors. [...] If we decide the price, this is not a random decision" (Franchise commercial director \#11, specialized food industry). Another franchisor went in the same direction saying: "Prices are not implemented any which way. They are studied to meet customer expectations, depending on the product sold. And the implementation of these prices allows us to both increase brand attractiveness through traffic [in the stores] through clear positioning, therefore generating traffic and customer fulfillment in a market that is very competitive" (Franchise director \#17, optometrist industry).

Another franchisee seemed to be conscious of this difficulty: "I know they [i.e., the franchisor] study everything at first. I know that margins are calculated correctly, neither too much nor too little. I could actually increase a little bit of my personal labor costs on making up a box [of chocolates], but if it doesn't sell.... I tell myself that, as they researched the right prices, I do not need to come and put my two cents in" (Franchisee \#16, specialized food industry). A franchisor explained that setting the right price involves taking into account several aspects, such as brand image, market conditions, etc.: "[We have to explain to our franchisee] the reason why, the why and the how, and demonstrate that we have thought about it anyway, that we have asked the right questions and that we have run the studies to prove what we are saying. [...] There are several things involved in [setting the right] price. Actually, there is the price positioning according to the brand image. What we want to convey in relation to our market, our competitors, etc. There is price positioning related to what the customers want theoretically in the national market. Finally, [we have to take into account] 
what actually takes place in the local market [with] market study. I think these are the three most important criteria for price positioning" (Chain founder \#1, fast food industry).

A few other interviewees provided other details about the criteria used to set the right prices. One said: "When we have a product and think about a price, we know how much we buy it for, we know how much the competitors sell it for, [...] we taste the product and we know how much we would be willing to buy it for if we were a consumer, and compared to the range, where it's in our range and, in terms of quality, what price we can apply. [...] So, to sum: it's competitors, it's the purchasing price, [...] it's the market in general, it's quality. It depends on the year, too, which means that there are certain times in the year when we have to do the promotion. [...] So, we must be very careful with our resale prices" (On-field consultant \#16, specialized food industry).

Another interviewee added: "Well, how are they calculated? In fact, it's the result of... basically there are many, many things. [...] They're based on the cost of the raw materials, [...] soaring butter prices inevitably affect the purchase price. [And also] all the macro elements, the VAT increases, things like that. The competition records/benchmarking because they do a lot of competitive records/benchmarking to see what is happening out there" (Onfield consultant \#5, fast food industry). Still another interviewee offered: "[The resale price], it's relative to the margin that we have to respect $[\ldots]$, relative to the quality of the product, relative to the competition... How much it can be sold by the competitor. [...] So that's it, competition, market and then market price too" (Director of chain development \#8, specialized food industry). 


\subsubsection{Importance of franchisor experience in company-owned stores in setting the right recommended resale prices}

Several interviewees mentioned the relevance of a plural form chain, and thus the existence of company-owned stores within the chain, because such franchisors have experience through their company-owned stores. One franchisor said that they were fortunate to have companyowned stores in their chain: "We have a pricing policy that is implemented in our companyowned stores for a product, a new product $[\ldots]$. We do market research on that $[\ldots]$, and then we inform our franchisees about the products, the price positioning of the products and the meaning we give to this positioning. [...] We're lucky [...] to have a plural form chain. We have [number] stores that are a real laboratory for us. I always say to my franchisees 'we have a fabulous luck'. [...] As soon as we put a commercial policy in place, it has been tested beforehand in our [company-owned] stores, or in some of [them]. We precisely settled this price positioning beforehand. [...] We are lucky. It is not a blank page saying, 'Well, we'll put it in place, we'll see'. We benefit from everything that has been done before in the company-owned stores, and by these laboratories. It allows us to put in place something that works. It's a real opportunity. [...] We must actually allow the franchisee who joins the chain [Brand] to avoid having to ask 36000 questions about what price he has to affix on this product, to be in tune with the expectations of the customer, because we did it beforehand with our company-owned stores" (Franchise director \#17, optometrist industry).

Another franchisor in the home care industry added: "[Our] franchisees are expecting us to know what we are going to do in terms of resale price or resale price increase [...] because we have [number] stores that belong to us and they are aware that we are as attentive as they are to the business model that we have in our stores. [...]. The credibility that we have today, as the head of the chain which continues the development of company-owned stores, and which has been on-going for more than 21 years, it is enormous because when we buy 
agencies [...], it sends s a message to our franchisees. Our creed is not 'Do what I say, but don't do what I do' or 'Do what I say, without me practicing it in my own stores'. [...] In the company-owned agencies [...], we apply what we ask them to do" (Chain CEO \#12, home care industry).

In the fast food industry, as well, the experience of the company-owned stores was highlighted: "It would be completely wrong [for the franchisee] not to benefit from the experience that we can bring him/her via our company-owned stores. [...] If he/she wants to set his/her own prices, he/she can [...] but I don't think it is his/her interest, and [our franchisees] have never manifested themselves in this way" (On-field consultant \#5, fast food industry). A franchisee also noted the importance of being in a chain where there are company-owned stores, explaining: "[At headquarters], there are people who [...] are direct managers and $[\ldots]$ sales people. They are not finance guys first. They are sales people first. And, in fact, they have very good knowledge of the business, and the margin levels they offer are rather good margins. At [Brand], you have recommended prices. That's well done. This is because they [the founders of the chain] run [company-owned] stores. The management team [at the headquarters] directly runs some stores so they know the profit and loss accounts by heart. That's important. [...] These people at [headquarters] have business approaches to things. That's important" (Franchisee \#38, specialized food industry).

\subsubsection{Franchisee participation in setting the right recommended resale prices}

Several interviewees explained that franchisees can be formally involved in setting the right recommended resale prices via committees. A committee usually gathers a few franchisees (6 to 10 on average) and a couple of staff members from the chain headquarters. They meet regularly and work on topics such as pricing, innovation, Internet, products, advertising. With 
the input of the franchisees through this team work, setting the right recommended prices is easier.

A franchisor noted: "Once we have done that [calculate the resale price], it is presented to the committee. We have representative authorities and we present it to the commission that is competent in it, even if it is consultative. We consult and decide, we disseminate and then we transmit it to the franchisees" (Franchise commercial director \#11, specialized food industry). A franchisee also shared with us his point of view on the role of franchisees in setting recommended prices as a result of their participation on the committees: "Resale prices are decided [...] by the marketing committee, which means headquarters and the franchisees, period. [...] The work of the marketing committee is to approve, to send information from the bottom, that is the franchisees, but it is also to pass on information from the headquarters to the franchisees. [...] What price? The marketing committee thinks, they work. They say, we tested, we tested in 2, 3, 4 stores, it works, people are satisfied, and it will cost us that. We will earn that, etc., etc. The franchisees say, 'OK, here we go"' (Franchisee \#14, fast food industry).

Some other interviewees said that franchisees can informally participate in setting the right recommended resale prices through feedback, for instance. A franchisor explicitly mentioned this: "We have the price grid. That is to say we will offer different prices for the menus, and we will actually revise them according to franchisee feedback" (Regional manager \#15, specialized food industry). Another interviewee talked about joint work on the determination of the right price involving the franchisee and his/her on-field consultant saying: "We study the average prices at the national level. We transfer the prices and then the franchisee will check with his on-field consultant or another person from headquarters to analyze what is happening regarding the competition in his/her area" (Head of chain development \#2, retail industry). 
Because setting the right recommended resale prices mainly relies on franchisor capabilities and experience acquired in the company-owned stores, is a difficult task and requires in some cases the involvement of franchisees, we can formulate the following proposition:

Proposition 2: Recommended resale prices are part of the franchisor organizational knowhow.

\section{DISCUSSION}

\section{1. Summary of findings}

This paper provides primary evidence on integration of resale pricing in the franchisor knowhow as suggested in Figure 1. To assess the pricing capabilities embedded in know-how, we draw upon insights from alliance capabilities research (Simonin, 1997; Gillis et al., 2020) and business-to-business research (Blachetta and Kleinaltenkamp, 2019; Dutta et al., 2003;

Johansson et al., 2015; Suh et al. 2019). The price, as a marketing-mix element, is particularly sensitive in franchise chains, because anti-trust laws prevent franchisors from imposing resale prices on their franchisees. Franchisors, moreover, need a high level of standardization in the marketing of their businesses. Our findings show that resale pricing, on top of being a marketing-mix element, is also part of the franchisor's know-how, and, more specifically, both part of the specialized business know-how and part of the broad organizational knowhow.

On the one hand, interviewees explained how franchisors transfer their recommended resale prices to their franchisees. They listed several ways this occurs: training sessions, onfield consultants, Intranet and the operations manual. This is consistent with the findings of Perrigot et al.'s (2017) research on know-how transfer in franchise chains. Indeed, they 
pointed out that these means of know-how transfer from a general perspective, as part of the transfer of the business template, but there is no focus on recommended resale prices in particular. Moreover, interviewees said that franchisors use different tools with which to transfer their recommended resale prices and/or the techniques to set their resale prices. These tools are grids, scales, ranges, lists, etc. Our empirical findings showed that recommended resale prices and information on these prices are transferred from the franchisor to the franchisees, as is the case for other elements of know-how, e.g., recipes of pizzas for the pizza chains, sales techniques for chains in the real estate industry, store layout for ready to wear chains. Proposition 1: "Recommended resale prices are part of the franchisor business knowhow" emerged from the findings of our research; it could be empirically tested in a future empirical study based on a questionnaire-based survey on franchisors and/or franchisees.

On the other hand, interviewees shed light on the complexity of calculating the right prices. This determination depends on several criteria, including the cost of the raw materials, the competition, the demand, some macro elements like VAT increases or the expected margin. Franchisees are usually not trained to calculate the right prices on their own, due to the inherent difficulties reminded above, and also in the perspective of preventing opportunistic imitation if all knowledge is transferred, as noticed by Suh et al. (2019) in the context of partnerships. From this perspective, the involvement of the franchisor in the operation of company-owned stores, as well as the involvement of franchisees in such decision making, via committees, for instance, appear to have a positive impact on setting recommended prices, similarly to other collaborations in marketing activities in business-tobusiness relationships (Blachetta and Kleinaltenkamp, 2019) and increasing commitment to adhering to them (see Bradach, 1998). All these elements underline that setting the right recommended prices requires capabilities of various departments at the franchise chain headquarters, then supporting Blachetta and Kleinaltenkamp (2019) findings in business-to- 
business settings, and therefore pricing relies on organizational know-how. Proposition 2:

"Recommended resale prices are part of the franchisor organizational know-how" emerged from the findings of our research; as the first proposition, it could also be empirically tested in a future empirical study based on a questionnaire-based survey on franchisors and/or franchisees.

\subsection{Contributions to the literature}

This research contributes to the literature on business-to-business marketing and, more specifically, on franchising. By examining how franchisors transfer recommended resale prices to their franchisees as part of their know-how, we build on two streams of the franchising literature. First, we extend the literature on resale pricing in franchising (e.g., Ater and Rigbi, 2015; Basset and Perrigot, 2015; Perrigot and Basset, 2018; Perrigot et al., 2016) by showing that resale pricing is part of both business and organizational know-how. Most papers deal with the legal aspects of resale pricing in franchising associated with franchisee autonomy in price setting (Basset and Perrigot, 2015). In this paper, we showed that resale pricing is part of franchisor know-how and not only an area of autonomy for franchisees. In fact, drawing parallels between the findings of Hinterhuber and Liozu (2014)'s study in a general business-to-business context and our franchise context, setting up the right prices is a franchisor capability that can be a source of competitive advantage for both businesses, the franchisee's one and the franchisor's one. Franchisors cannot overlook those practices of setting up the appropriate price. Our interviews were able to highlight the practical means by which franchise chains manage their pricing. In particular, we have shown the complexity of the process, which provides a rich understanding of the franchising context and complements the literature that has tended to focus on broad insights without achieving a deep level of knowledge of actual practices. 
Moreover, we build on the literature dealing with know-how in franchising by first analyzing a neglected aspect of know-how, that is, resale prices, and secondly pointing out the links between business, organizational know-how and competitive advantage. The literature on know-how in franchising generally addresses business know-how transferred to franchisees (Knott, 2003; Perrigot et al., 2017). In this paper, we highlighted the existence of another kind of know-how, organizational know-how, which refers to franchisor capabilities as recently explained by Gillis et al. (2020). The description we made of its complexity corroborates its potential to generate competitive advantage, additionally to the explicit knowledge transferred to franchisees in operation manuals and on the Intranet. Moreover, a certain level of transfer of institutionalized knowledge ${ }^{8}$ has been found to damage partnerships (Suh et al., 2019) in the form of unintended benefits of the recipient and some balance must be achieved. Some of this institutionalized knowledge may be embedded in organizational know-how linked to resale pricing. This is important because the franchising literature is largely focused on business know-how and could largely benefit from studying organizational know-how.

Finally, responding to Perrigot and Basset (2018), we used a dual approach involving franchisor and franchisee perspectives. This approach, compared to a one-sided franchisor- or a franchisee-based approach, offers a more accurate understanding of resale pricing as part of franchisor know-how. Franchising research in general could greatly benefit from such designs that are likely to increase our understanding of the dynamics between franchisors and franchisees within chains.

\footnotetext{
${ }^{8}$ Suh et al. (2019, p. 866) define institutionalized knowledge as "pertaining to systematic, strategic management of its supply chain relationship".
} 


\subsection{Contributions to practice}

The contributions of this study are threefold. Firstly, we showed that resale pricing is part of franchisor know-how. As far as business know-how is concerned, this part of know-how has to be codified in the operations manual and transferred to the franchisees using several tools, including training sessions, on-field consultants, etc. Using both, written and oral transfer is complementary and allows franchisees to better absorb this know-how. Not only do the recommended prices have to be transferred, but also, many times, parts of the methods (capabilities) to calculate the right price have to be as well. It is important for the franchisees, as independent small business owners, to understand how to set up the right price. Regarding organizational know-how, determining the right recommended prices is not easy and requires capabilities at headquarters and, in many cases the involvement of franchisees in committees dedicated to resale pricing. For instance, in the hotel industry, most franchise chains do recruit revenue or yield managers, that are experts in selling rooms and services (conference rooms, spa, etc.) at the best prices for achieving a maximal profitability at the hotel level. To sum up, this paper may help franchisors to better understand the complexity of resale pricing and its integration into know-how. This is essential because pricing issues are central to the principles of franchising, and framing them as know-how highlights their importance to franchisors and franchisees. It also stresses the importance of designing proper internal mechanisms, such as competition benchmarking, consideration of franchisee feedback, to achieve optimal pricing strategies.

Secondly, we have identified the existence of another kind of know-how apart from business know-how that is transferred to the franchisees. Indeed, organizational know-how is often neglected, although it is a necessary ingredient for sustaining a competitive advantage. This know-how is not necessarily transferred to the franchisees because of inherent difficulties to do so, but also in order to protect the franchisor resources and capabilities from 
imitation, thus contributing to the longevity and success of the franchisor/franchisee relationship (Harmon and Griffiths, 2008). Franchisors should thus work on improving their capabilities to better assist their franchisees. This is especially important in the contemporary franchising environment, which has become more competitive in face of the growth in the number of chains and the relative decline in the number of skilled franchisees. In other words, organizational know-how has the potential to differentiate high-performing chains both in terms of business performance and chain growth, in a context where more knowledge about understanding the reasons for chain growth is needed (Kang et al., 2018). In addition to resale pricing, other dimensions of organizational know-how can be mentioned: communication, franchisee integration in the chain, e-commerce, logistics, etc.

Thirdly, this paper provides new insight for considering the role of resale prices in future anti-trust legislation that is concerned with price effects on competition in the marketplace and its consequences for consumers. We have broadened the analysis of price setting in franchising by considering the process of calculation as part of franchisor knowhow. Therefore, it becomes an instrument to improve business offerings to consumers, not just a means to directly increase franchisor revenues. As such, it may also contribute to public policy decisions about franchising. Adding the pricing know-how dimension to the legal dimension in the discussion on pricing issues may potentially legitimate the role of franchising in achieving an efficient and competitive retailing system.

\subsection{Limitations and tracks for future research}

This paper has some limitations. Firstly, the qualitative approach presents by itself some limitations about the generalization of our findings. In future research, we could adopt a quantitative approach with a questionnaire-based survey of franchisors and/or franchisees to be more specific about the relationships between resale pricing and know-how. Further 
questions could also be examined: Is resale pricing part of central or peripheral know-how? What about codifiability and teachability of the know-how dealing with resale prices? What about franchisee compliance in terms of resale pricing? Are there significant differences in terms of integration of resale pricing in franchisor know-how depending on the industry: retailing vs. services?

Secondly, the empirical study focused on franchising in France. The study of the integration of resale pricing in franchisor know-how could be explored at the European level, due to the impact of the European Commission regulation, as well as in other countries such as Australia, Canada, the US, and Asian countries where franchising is well developed. A comparison between Europe and the United States of America could be particularly relevant, because of the different roles given to know-how in these two geographical zones and their different regulation frameworks. 


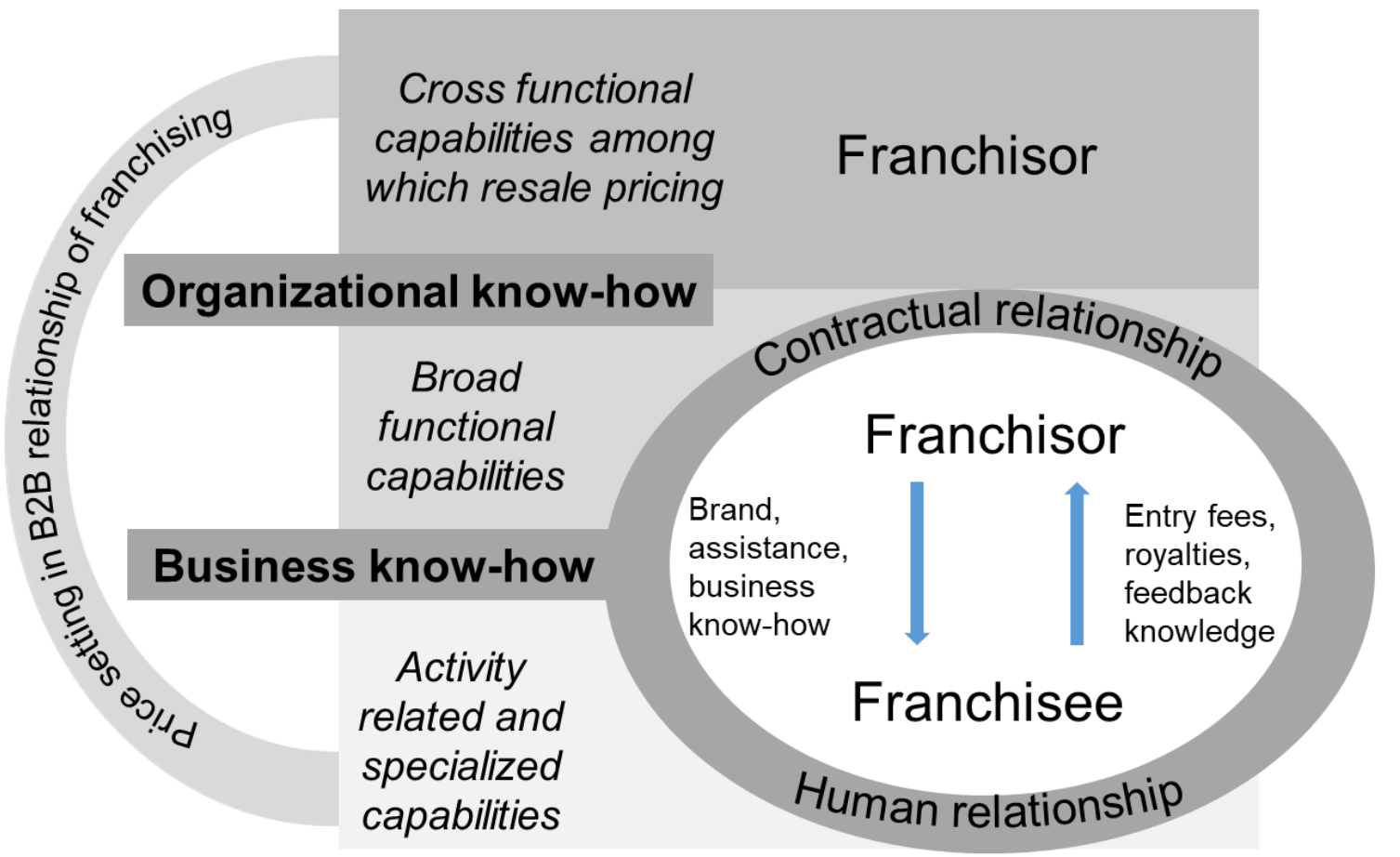

Figure 1: Hierarchy of capabilities in franchising and resale pricing as part of franchisor know-how 


\section{REFERENCES}

Arhel, P. (2001), "Lutte contre les pratiques de prix minimum imposés en Europe", Les Petites Affiches, Vol. 229 No. 4, pp. 4-10.

Ater, I. and Rigbi, O. (2015), "Price control and advertising in franchising chains", Strategic Management Journal, Vol. 36, pp. 148-158.

Barney, J.B. (2002), "Strategic management: From informed conversation to academic discipline", The Academy of Management Executive, Vol. 16 No. 2, pp. 53-57.

Basset, G. and Perrigot, R. (2015), “Franchisees' resale price policy facing legal, contractual and professional constraints: Insights from European and French perspectives", Research in Law and Economics, Vol. 27, pp. 119-142.

Blachetta, M. and Kleinaltenkamp, M. (2019), "Dispersion of marketing activities in businessto-business firms", Journal of Business \& Industrial Marketing, Vol. 34 No. 6, pp. 11601170 .

Blair, R.D. and Lafontaine, F. (2005), The economics of franchising, Cambridge University Press.

Bordonaba-Juste, V., Lucia-Palacios, L. and Polo-Redondo, Y. (2011), "An analysis of franchisor failure risk: evidence from Spain", Journal of Business \& Industrial Marketing, Vol. 26 No. 6, pp. 407-420.

Bradach, J.L. (1997), "Using the plural form in the management of restaurant chains", Administrative Science Quarterly, Vol. 42, pp. 276-303.

Bradach, J.L. (1998). Franchise organizations. Boston, MA: Harvard Business School Press.

Collis, D.J. and Montgomery, C.A. (1995), "Competing on resources", Harvard Business Review, July-August, pp. 118-128.

Croonen, E. (2010), "Trust and fairness during strategic change processes in franchise systems”, Journal of Business Ethics, Vol. 95 No. 2, pp. 191-209.

Dierickx, I. and Cool, K. (1989), “Asset stock accumulation and sustainability of competitive advantage", Management Science, Vol. 35, pp. 1504-1511.

Doherty, A.M. (2009), "Market and partner selection processes in international retail franchising", Journal of Business Research, Vol. 62 No. 5, pp. 528-534. 
Doherty, A.M. and Alexander, N. (2004), "Relationship development in international retail franchising: Case study evidence from the UK fashion sector", European Journal of Marketing, Vol. 38 No. 9/10, pp.1215-1235.

Dutta, S., Zbaracki, M.J. and Bergen, M. (2003), "Pricing process as a capability: A resourcebased perspective", Strategic Management Journal, Vol. 24 No. 7, pp. 615-630.

El Akremi, A., Mignonac, K. and Perrigot, R. (2011), "Opportunistic behaviors in franchise chains: The role of cohesion among franchisees", Strategic Management Journal, Vol. 32 No. 9, pp. 930-948.

Etikan, I., Musa, S.A. and Alkassim, R.S. (2016), "Comparison of convenience sampling and purposive sampling", American Journal of Theoretical and Applied Statistics, Vol. 5 No. 1, pp. 1-4.

European Code of Ethics for Franchising, https://www.franchise-fff.com/franchise/le-cadrereglementaire/le-code-de-deontologie-europeen (accessed 26 April 2018).

French Franchise Federation (2018), https://www.franchise-fff.com/franchise/les-chiffres-cles (accessed 26 April 2018).

Frazer, L., Weaven, S., Giddings, J. and Grace, D. (2012), "What went wrong? Franchisors and franchisees disclose the causes of conflict in franchising", Qualitative Market Research: An International Journal, Vol. 15 No. 1, pp. 87-103.

Frazer, L. and Winzar, H. (2005), "Exits and expectations: Why disappointed franchisees leave", Journal of Business Research, Vol. 58 No. 11, pp. 1534-1542.

Gillis, W.E., Combs, J.G. and Yin, X. (2020), "Franchise management capabilities and franchisor performance under alternative franchise ownership strategies", Journal of Business Venturing, Vol. 35 No. 1 DOI: 10.1016/j.jbusvent.2018.09.004.

Glaser, B. and Strauss, A. (1967), The Discovery of Grounded Theory: Strategies for Qualitative Research. Mill Valley, CA: Sociology Press.

Grant, R.M. (2016), Contemporary strategy analysis: Text and cases edition. John Wiley \& Sons.

Grant, R.M. and Jordan, J.J. (2015), Foundations of strategy. John Wiley \& Sons.

Harmon, T. and Griffiths, M. (2008), "Franchisee perceived relationship value", Journal of Business \& Industrial Marketing, Vol. 23 No. 4, pp. 256-263. 
Hinterhuber, A. and Bertini, M (2011), “Profiting When Customers Choose Value Over Price”. Business Strategy Review, Vol. 22 No. 1, pp. 46-49.

Hinterhuber, A. and Liozu, S.M. (2014), "Is innovation in pricing your next source of competitive advantage?". Business Horizons, Vol. 57 No. 3, pp. 413-423.

Hoy, F., Perrigot, R. and Terry, A. (2017), Handbook of Research on Franchising, Edward Elgar Publishing.

Huberman, M. and Miles, M.B. (2002), The Qualitative Researcher's Companion. Thousand Oaks: Sage.

Iddy, J.J. and Alon, I. (2019), "Knowledge management in franchising: a research agenda", Journal of Knowledge Management, Vol. 23 No. 4, pp. 763-785.

Johansson, M., Keränen, J., Hinterhuber, A., Liozu, S. and Andersson, L. (2015), "Value assessment and pricing capabilities - how to profit from value", Journal of Revenue and Pricing Management, Vol. 14 No. 3, pp. 178-197.

Kang, J., Asare, A. K., Brashear-Alejandro, T. and Li, P. (2018), "Drivers of franchisor growth: A meta-analysis", Journal of Business \& Industrial Marketing, Vol. 32 No. 2, pp. 196207.

Kaufmann, P.J. and Eroglu, S. (1999), "Standardization and adaptation in business format franchising”, Journal of Business Venturing, Vol. 14 No. 1, pp. 69-85.

Kim, M. and Stepchenkova, S. (2018), "Does environmental leadership affect market and eco performance? Evidence from Korean franchise firms", Journal of Business \& Industrial Marketing, Vol. 33 No. 4, pp. 417-428.

Kirby, D. and Watson, A. (1999), "Franchising as a small business development strategy: A qualitative study of operational and "failed" franchisors in the UK", Journal of Small Business and Enterprise Development, Vol. 6 No. 4, pp.341-349.

Knott, A.M. (2003). "The organizational routines factor market paradox", Strategic Management Journal, Vol. 24 No. 10, pp. 929-943.

Kosová, R. and Lafontaine, F. (2012), "Much ado about chains: A research agenda", International Journal of Industrial Organization, Vol. 30 No. 3, pp. 303-308. 
Lafontaine, F. (1992), “Agency theory and franchising: Some empirical results”, Rand Journal of Economics, Vol. 23 No. 2, pp. 263-283.

Lafontaine, F. (1999), "Franchising versus corporate ownership: The effect on price dispersion", Journal of Business Venturing, Vol. 14 No. 1, pp. 17-34.

Lafontaine, F. and Morton, F.S. (2010), "Markets, state franchise laws, dealer terminations, and the auto crisis", Journal of Economic Perspectives, Vol. 24 No. 3, pp. 233-250.

Lee, Y., Kim, S., Kim, M., Lee, J. and Lim, K. (2015), "Relational bonding strategies in the franchise industry: the moderating role of duration of the relationship", Journal of Business \& Industrial Marketing, Vol. 30 No. 7, pp. 830-841.

Liozu, S.M. and Hinterhuber, A. (2013), "Pricing orientation, pricing capabilities, and firm performance", Management Decision, Vol. 51 No. 3, pp. 594-614.

Michael, S.C. (1999), "The elasticity of franchising”, Small Business Economics, Vol. 12 No. 4, pp. 313-320.

Mignonac, K., Vandenberghe, C., Perrigot, R., El Akremi, A. and Herrbach, O. (2015), “A multi-study investigation of outcomes of franchisees' affective commitment to their franchise organization", Entrepreneurship Theory and Practice, Vol. 39 No. 3, pp. 461488.

Miles, M.B., Huberman, A.M. and Saldaña, J. (2014), Qualitative Data Analysis: A Methods Sourcebook, Third edition. SAGE Publications.

Morse, J.M., Barrett, M., Mayan, M., Olson, K., Spiers, J. (2002), "Verification Strategies for Establishing Reliability and Validity in Qualitative Research", International Journal of Qualitative Methods, Vol. 1 No. 2, pp. 13-22.

Newbert, S.L. (2008), "Value, rareness, competitive advantage, and performance: A conceptual-level empirical investigation of the resource-based view of the firm", Strategic Management Journal, Vol. 29 No. 7, pp. 745-768.

Nonaka, I., Toyama, R. and Konno, N. (2000), “SECI, Ba and leadership: A unified model of dynamic knowledge creation”, Long Range Planning, Vol. 33 No. 1, pp. 5-34.

Pardo-del-Val, M., Martínez-Fuentes, C., López-Sánchez, J.I. and Minguela-Rata, B. (2014), "Franchising: the dilemma between standardisation and flexibility", Service Industries Journal, Vol. 34 No. 9-10, pp. 828-842. 
Paswan, A.K. and Wittmann, C.M. (2009), "Knowledge management and franchise systems", Industrial Marketing Management, Vol 38 No. 2, pp. 173-180.

Perrigot, R. and Basset, G. (2018), "Resale pricing in franchised stores: A franchisor perspective", Journal of Retailing and Consumer Services, Vol. 43, pp. 209-217.

Perrigot, R., Basset, G. and Meiseberg, B. (2016), "Resale prices in franchising: Insights from franchisee perspectives”, Journal of Product and Brand Management, Vol. 25 No. 7, pp. 663-675.

Perrigot, R. and Herrbach, O. (2012), "The plural form from the inside: A study of franchisees' perceptions about the existence of company-owned outlets within their network”, International Journal of Retail \& Distribution Management, Vol. 40 No. 7, pp. 544-563.

Perrigot, R., Herrbach, O., Cliquet, G. and Basset, G. (2017), "Know-how transfer mechanisms in franchise networks: A study of franchisee perceptions", Knowledge Management Research \& Practice, Vol. 15, pp. 272-281.

Perrigot, R., Herrbach, O. and El Akremi, A. (2011), “L'impact de la mixité sur la maîtrise des savoir-faire organisationnels des franchiseurs", Economies et Sociétés, Vol. 13 No. 6, pp. 1007-1024.

Reed, R. and DeFillippi, R. (1990), "Causal ambiguity, barriers to imitation, and sustainable competitive advantage", Academy of Management Review, Vol. 15, pp. 88-102.

Saldaña, J. (2015), The Coding Manual for Qualitative Researchers, 3rd edition. Sage Publications.

Simonin, B. (1997), "The importance of collaborative know-how: An empirical test of the learning organization", The Academy of Management Journal, Vol. 40 No. 5, pp. 11501174.

Sorenson, O. and Sørensen, J. B. (2001), "Finding the right mix: Franchising, organizational learning, and chain performance". Strategic Management Journal, Vol. 22 No 6-7, pp. 713-724.

Stassen, R. (2017), "Resale price maintenance in franchising: market coverage, companyowned stores, and retailer dependence", in Hoy, F., Perrigot, R., and Terry, A. (Eds), Handbook of Research on Franchising, Edward Elgar Publishing, pp. 249-272. 
Suh, T., Jung, J. C., Zank, G. M. and Arend, R. J. (2019), “Twofold relationship dynamics of supplier's knowledge sharing”, Journal of Business \& Industrial Marketing, Vol. 34 No 4, pp. 862-874.

Vázquez, L. (2008), "The choice of control devices in franchise chains". Service Industries Journal, Vol. 28 No. 9, pp. 1277-1291.

Watson, A., Stanworth, J., Healeas, S., Purdy, D. and Stanworth, C. (2005), "Retail franchising: An intellectual capital perspective", Journal of Retailing and Consumer Services, Vol. 12 No. 1, pp. 25-34.

Weaven, S. and Frazer, L. (2006), "Investment incentives for single and multiple unit franchisees”, Qualitative Market Research: An International Journal, Vol. 9 No. 3, pp. 225-242.

Weaven, S. and Frazer, L. (2007), "Expansion through multiple unit franchising: Australian franchisors reveal their motivations", International Small Business Journal, Vol. 25 No. 2, pp. 173-205.

Wernerfelt, B. (1984), “A resource-based view of the firm”, Strategic Management Journal, Vol. 5, pp. 171-180.

Windsperger, J. and Gorovaia, N. (2011), "Knowledge attributes and the choice of knowledge transfer mechanism in networks: the case of franchising", Journal of Management and Governance, Vol. 15 No. 4, pp. 617-640.

Winter, S. G., Szulanski, G., Ringov, D. and Jensen, R. J. (2012), "Reproducing knowledge: Inaccurate replication and failure in franchise organizations". Organization Science, Vol. 23 No 3, pp. 672-685.

Yin, R. (2003). Case Study Research: Design and Methods (3rd ed.). Thousand Oaks: Sage Publications.

Zanarone, G. (2009), "Vertical restraints and the law: Evidence from automobile franchising", Journal of Law and Economics, Vol. 52 No. 4, pp. 691-692.

Zhang, J.J., Lawrence, B. and Anderson, C.K. (2015), “An agency perspective on service triads: Linking operational and financial performance”, Journal of Operations Management, Vol. 35, pp. 56-66. 